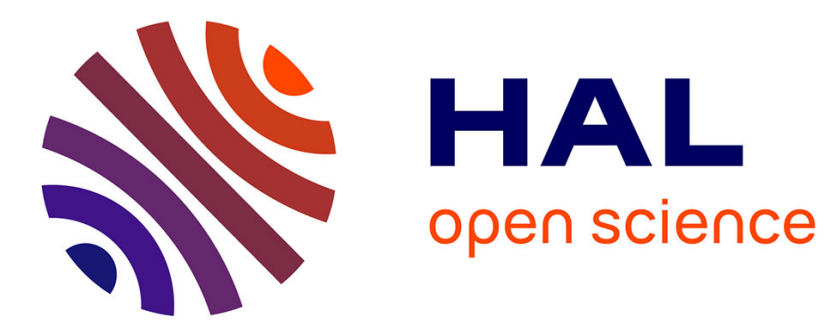

\title{
Recent Improvements of Ferrite Magnets
}

\author{
H. Taguchi
}

\section{To cite this version:}

H. Taguchi. Recent Improvements of Ferrite Magnets. Journal de Physique IV Proceedings, 1997, 07 (C1), pp.C1-299-C1-302. 10.1051/jp4:19971118 . jpa-00254758

\section{HAL Id: jpa-00254758 https://hal.science/jpa-00254758}

Submitted on 1 Jan 1997

HAL is a multi-disciplinary open access archive for the deposit and dissemination of scientific research documents, whether they are published or not. The documents may come from teaching and research institutions in France or abroad, or from public or private research centers.
L'archive ouverte pluridisciplinaire HAL, est destinée au dépôt et à la diffusion de documents scientifiques de niveau recherche, publiés ou non, émanant des établissements d'enseignement et de recherche français ou étrangers, des laboratoires publics ou privés. 


\title{
Recent Improvements of Ferrite Magnets
}

\author{
H. Taguchi \\ TDK Materials Research Center, 570-2 Matugashita, Minamihatori, Narita, Chiba 286, Japan
}

\begin{abstract}
This paper overviews recent improvements in the properties of ferrite magnets from two viewpoints. First, new processes for submicron-sized particles, for high orientation and for high density were studied in detail. As a result, high performance $\mathrm{Sr}$-ferrite magnets with $\mathrm{Br}=0.44 \mathrm{~T}(4.4 \mathrm{kG})$ and $\mathrm{HcJ}=320 \mathrm{kA} / \mathrm{m}(4.0 \mathrm{kOe})$ were developed. Furthermore, by means of $\mathrm{SiO}_{2}-\mathrm{SrO}$ or $\mathrm{SiO}_{2}-\mathrm{BaO}$ addition, high performance $\mathrm{Ba}$-ferrite magnets with $\mathrm{Br}=0.43 \mathrm{~T}(4.3 \mathrm{kG}), \mathrm{HcJ}=290 \mathrm{kA} / \mathrm{m}$ $(3.6 \mathrm{kOe})$ were obtained. At the same time, we discovered that it is possible to make equal the shrinkage ratio in the $a$-and $c$-axes. Second, ( $\mathrm{LiFe}) \mathrm{Zn} W$-ferrite and $\mathrm{Zn}$-substituted $M$-ferrite were investigated. Consequently, LaZn substituted $\mathrm{Sr} M$ ferrite magnets were developed with extremely good properties, viz. $\mathrm{Br}=0.46 \mathrm{~T}(4.6 \mathrm{kG})$ and $(\mathrm{BH}) \mathrm{max}=41 \mathrm{~kJ} / \mathrm{m}^{3}(5.2 \mathrm{MGOe})$.
\end{abstract}

\section{INTRODUCTION}

More than 40 years have passed since the first announcement of Ba-ferrite by Philips [1]. Since then hexa-ferrite magnets have become widely used in many electronic products, which is explained mainly by their unsurpassed cost efficiency. Another advantage is the chemical stability of these oxides which makes them environmentally safe, further establishing their continued use. On the other hand, a great number of attempts have been made to improve the properties. These technics or methods are classified into two groups. First is the processing technic for obtaining submicron sized powder, high orientation and density for micro- and nano-structure control. Second is the spin-structure control technic to improve fundamental properties such as saturation magnetization and/or magnetic anisotropy. This paper overviews studies at TDK employing these two approaches.

\section{PROCESS FOR HIGH PERFORMANCE FERRITE MAGNETS}

\subsection{Process for submicron powder}

It is assumed that coercivity in ferrite magnets originates in the magnetic behavior of single domain particles with uniaxial magneto crystalline anisotropy [2]. The critical diameter, below which a single domain is stable, is estimated at around $1 \mu \mathrm{m}$ for $\mathrm{Sr} M$-ferrite. Therefore, control of grain size to under a micron is significant for achieving high HcJ.

Taking into account grain growth, ferrite particles should be around 0.3 $\mu \mathrm{m}$ before sintering. However, particles prepared by the co-precipitation method, hydrothermal synthesis or by glass crystallization are too small (under $0.1 \mu \mathrm{m}$ ) to be orientated well in a magnetic field. Research at TDK has therefore centered on "ceramic-method" for obtaining submicron particles having adequate size $(0.1 \sim 1 \mu \mathrm{m})$ to produce sintered magnets. From this point of view, raw materials having small particle size should be mixed very well and calcination temperatures lowered; the molar ratio $\mathrm{Fe} 2 \mathrm{O} 3 / \mathrm{SrO}$ should be around stoichmetric $(6.0)$ to inhibit grain growth.

In the first place, the wet mixing method for raw materials ( $\mathrm{Fe}_{2} \mathrm{O}_{3}$ at $0.3 \mu \mathrm{m}$ and precipitated fine $\mathrm{SrCO}_{3}$ at $0.02 \mu \mathrm{m}$ ) was studied as the ideals [3]. As a result of further investigation, submicron particles were obtained using even commercial-grade raw materials. Figure 1 shows SEM images of mixed and wet-milled raw materials (after drying) and Sr-ferrite particles calcined at $1200^{\circ} \mathrm{C}$ (size of the primary particles $=0.2 \sim 0.8 \mu \mathrm{m}, \sigma \mathrm{s}=71$ $\mathrm{emu} / \mathrm{g}, \mathrm{HcJ}=5.3 \mathrm{kOe}$ ). Furthermore, very similar powders were also obtained by a dry mixing process using no liquid [4].

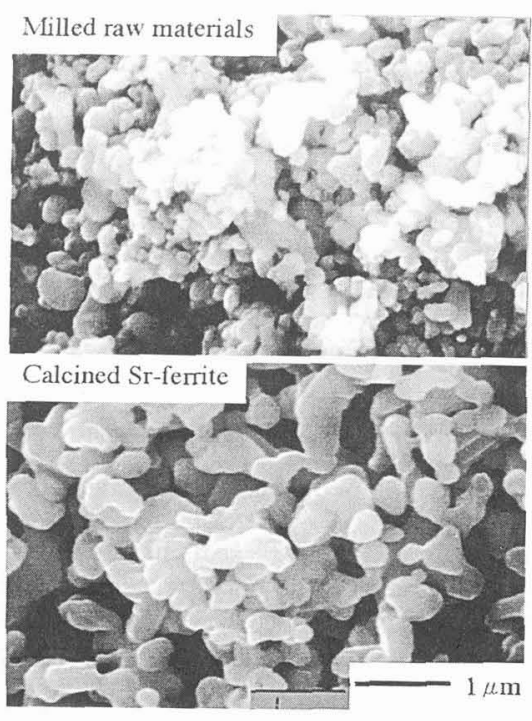

Figure 1: SEM images of mixed raw materials and calcined submicron Sr-ferrite particles. 


\subsection{Process for high orientation}

At the pressing stage, submicron sized particles are usually oriented with great difficulty in a magnetic field. It is essentially believed that the single domain particles attract each other magnetically creating agglomerates thus preventing orientation. Figure 2 shows an expected $B-H$ hysteresis curve of one hard-ferrite particle. Magnetic flux density at the working point $(\mathrm{B} 1)$, which is determined by the particle shape, relates to the magnetic agglomeration force. Therefore, the surface flux density of the particle must be reduced $(\mathrm{B} 1 \rightarrow \mathrm{B} 2)$ by reducing $\mathrm{HcB}$. On the other hand, the magnetic moment of the particle in a magnetic field (Hex) is proportional to Bs, which is best maximized. It was found that dryvibrating pulverization in particular was effective in reducing the Hc values $(\mathrm{HcJ}=5.5 \mathrm{kOe},(\mathrm{HcB}=4.6 \mathrm{kOe}) \rightarrow \mathrm{HcJ}(=\mathrm{HcB})=2.5 \mathrm{kOe})$ as shown in table 1 , by introducing lattice defects [5]; meanwhile the decrease of $\sigma \mathrm{s}$ (saturation magnetization per gram; $\propto \mathbf{B s}$ ) was within $10 \%$.

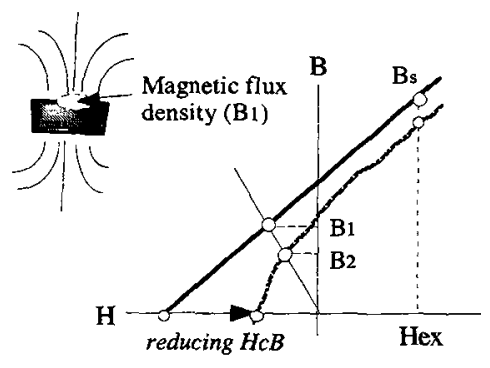

Figure 2: BH hysteresis curve of one $\mathrm{S}$-ferrite particle.

Table 1: Change of specific surface area (SBET), $\sigma \mathrm{s}$ and HcJ of dry vibration-pulverized powder. Line half-width (L.H.W.) was measured at (205) plane by XRD. Lattjce strain and crystallite size was determined using the Warren and Averbach method [6].

\begin{tabular}{|c|c|c|c|c|c|c|}
\hline Milling time (min.) & SBET $\left(\mathrm{m}^{2} / \mathrm{g}\right)$ & $\sigma \mathrm{s}(\mathrm{emu} / \mathrm{g})$ & Hcl $(\mathrm{kOe})$ & L.H.W (deg.) & Lattice strain & Crystallite size $(\AA)$ \\
\hline 0 & 2.9 & 70.7 & 5.54 & 0.108 & $7.87 \mathrm{e}-6$ & 1376 \\
\hline 5 & 3.4 & 68.0 & 3.52 & 0.126 & $7.27 \mathrm{e}-5$ & 315 \\
\hline 20 & 4.9 & 66.5 & 2.73 & 0.217 & $2.28 \mathrm{e}-4$ & 215 \\
\hline
\end{tabular}

Furthermore, the wet-process using an organic solvent (e.g. toluene or xylene) and surfactant (e.g. stearic acid or oleic acid) made a remarkable improvement in the degree of orientation for submicron particles as shown in fig.3, thus achieving high performance, anisotropic sintered magnets, with $\mathrm{Br}=0.44 \mathrm{~T}(4.4 \mathrm{kG})$ and $\mathrm{HcJ}=320 \mathrm{kA} / \mathrm{m}(4.0 \mathrm{kOe})[7]$.

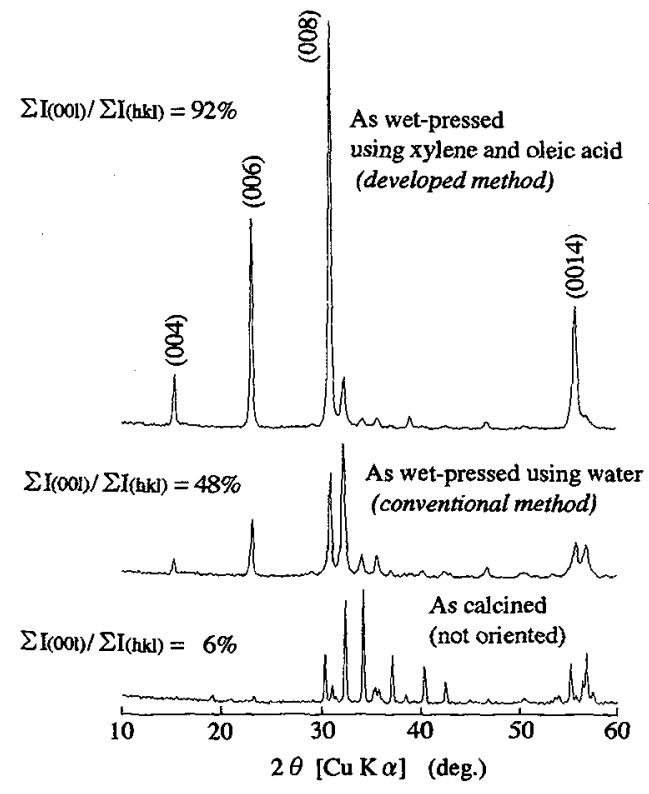

Figure 3: XRD pattern of submicron Sr-ferrite particles.
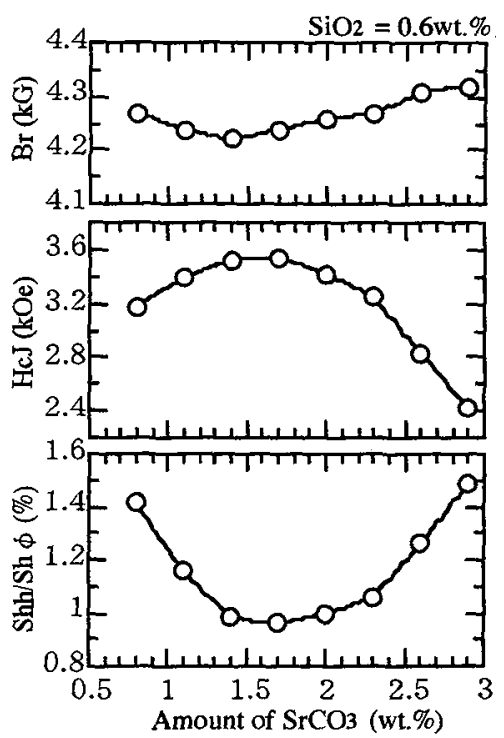

Figure 4: Dependence of $\mathrm{Br}, \mathrm{HcJ}$ and shrinkage ratio of $\mathrm{Ba}$-ferrite on amount of $\mathrm{SrCO} 3$.

\subsection{Additives for microstructure control and equal shrinkage ratio}

Addition of $\mathrm{SiO}_{2}$ and $\mathrm{CaCO} 3$ (or $\mathrm{CaO}$ ) is conventionally employed to $\mathrm{Ba}$ - or $\mathrm{Sr}$-ferrite in order to achieve high density and to inhibit grain-growth at the same time during final sintering. It is predicted that $\mathrm{Sr}$ or $\mathrm{Ba}$ can substitute for $\mathrm{Ca}$ without difficulty because they have similar characters. Therefore, the addition of alkaline-earth elements and silica to M-type alkalineearth-elements-ferrite was systematically investigated [8]. As fig.4 shows, the addition of adequate amounts of $\mathrm{SrCO}_{3}$ and $\mathrm{SiO}_{2}$ to Ba-ferrite improved $\mathrm{HcJ}$ and decreased the shrinkage ratio. Thus, the highest performance Ba-ferrite magnets $(\mathrm{Br}=0.43 \mathrm{~T}$ $(4.3 \mathrm{kG}), \mathrm{HcJ}=290 \mathrm{kA} / \mathrm{m}(3.6 \mathrm{kOe}))$ were obtained. It also becomes possible to make equal the shrinkage ratio in the $a$ and $c$ axes as shown in fig.5. Applying this material to multi-pole ring magnets (e.g. 24 or 36 poles), which are pressed under alternative magnetic field along the circumference, yielded a smooth surface after sintering as shown in fig.6. 


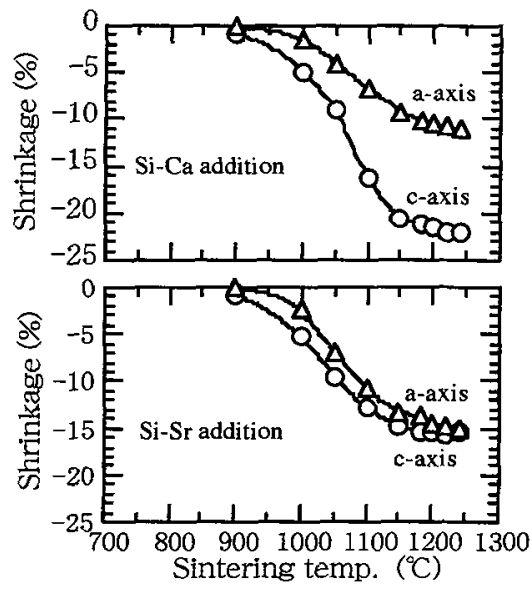

Figure 5: Shrinkage vs. sintering temperature of anisotropic Ba-ferrite with $\mathrm{Si}-\mathrm{Ca}$ and $\mathrm{S}-\mathrm{Sr}$.

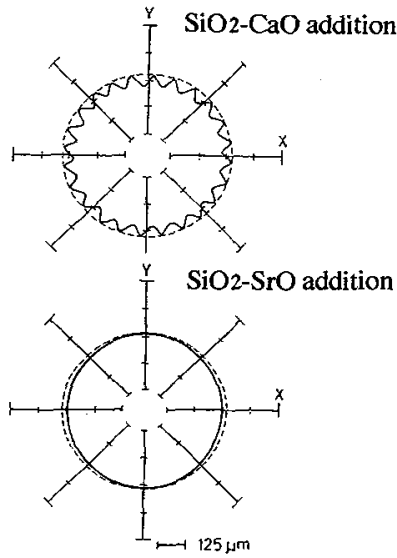

Figure 6: Comparison of the surface deformation of multi-pole ring magnets measured by a round tester.

These distinctive features were due to the inhibition of grain-growth along the a-axis, resulting in a small aspect ratio of the grains. According to TEM-EDS analysis, Ba segregation was found at the grain boundaries (triple points) besides Si and $\mathrm{Sr}$, as shown in table 2. This suggests the reaction between grains (Ba-ferrite) and glassy additives (Sr-silicates) during sintering. Furthermore, only when $\mathrm{SiO}_{2}-\mathrm{SrCO}_{3}$ or $\mathrm{SiO}_{2}-\mathrm{BaCO}_{3}$ were added to Ba-ferrite were increases in $\mathrm{HcJ}$ and an equal shrinkage ratio observed, as shown in table 3.

Table 2: Content ratio of triple-points to Ba-ferrite grains. Concentration of the elements were analyzed by TEM-EDS at more than

4 points. Bold figures represent obvious segregation at triple-points.

\begin{tabular}{|c|c|c|c|c|c|}
\hline & $\mathrm{Si}$ & $\mathrm{Ca}$ & $\mathrm{Ba}$ & $\mathrm{Sr}$ & $\mathrm{Fe}$ \\
\hline Si-Ca addition & $\mathbf{5 1 . 2}$ & $\mathbf{3 9 . 4}$ & 0.9 & 1.0 & $\mathbf{0 . 4}$ \\
\hline Si-Sr addition & $\mathbf{4 6 . 3}$ & $\mathbf{8 . 0}$ & $\mathbf{1 . 9}$ & $\mathbf{8 . 0}$ & $\mathbf{0 . 3}$ \\
\hline
\end{tabular}

Table 3: Combination of additives and $M$-ferrite. Anisotropic ferrite magnets with equal shrinkage ratio and higher $\mathrm{HcJ}$ are indicated by $\mathrm{O}$.

\begin{tabular}{|c|c|c|c|}
\hline & Si-Ca & Si-Sr & Si-Ba \\
\hline Sr-ferrite & - & - & - \\
\hline Ba-ferrite & - & 0 & 0 \\
\hline Ca-ferrite & - & - & - \\
\hline
\end{tabular}

\section{STUDY OF CRYSTAL STRUCTURE FOR HIGH PERFORMANCE FERRITE MAGNETS}

\subsection{W-type ferrite}

W-type ferrite magnets became the subject of much attention since the first announcement by Philips in 1980 [9]. They showed that $\mathrm{BaFe}^{2+} \mathrm{W}$ has a magnetization $(4 \pi \mathrm{Is}=5.1 \mathrm{kG}) 10 \%$ higher than $\mathrm{Ba} M$, and the anisotropy field is about equal $(\mathrm{HA}=18 \mathrm{kOe})$. Nevertheless, it is difficult to control the micro-structure, especially for high $\mathrm{Hc}$, because $\mathrm{Fe}^{2+} W$-phase formation requires a reducing atmosphere and higher temperature during sintering, followed by grain growth. Recently, $\mathrm{SrFe}^{2+} W$ with noticeable improvement by means of carbon addition has been reported [10].

On the other hand, $\mathrm{Zn}^{2+} \mathrm{W}$-type ferrite can be synthesized in air, but the anisotropy field is considerably low (HA=12kOe). Thus, with the aim of improving $\mathrm{HA}$, substitution of magnetic ions (such as $\mathrm{Li}^{+}+\mathrm{Fe}^{3+} \rightarrow \mathrm{Zn}^{2+}$ ) were studied at first, taking into consideration of the previous studies $[11,12]$. Consequently, the difference of the crystal stability between Sr- and Ba( $\mathrm{LiFe}) \mathrm{ZnW}$ after long milling was discovered, resulting in the divergent magnetic properties (Ir/Is, $\mathrm{Hk} / \mathrm{HcJ}$ ) as shown in table 4 [13]. When using $\mathrm{Ba}-(\mathrm{LiFe}) \mathrm{ZnW}$, a high $\mathrm{Br}$ value (4.6kG) was acheived, but $\mathrm{Hc}$ remained low (less than $1 \mathrm{kOe}$ ).

Table 4: Magnetic properties of (LiFe)ZnW-type ferrite magnets.

\begin{tabular}{|c|c|c|c|c|c|c|c|}
\hline & $4 \pi \mathrm{Is}(\mathrm{kG})$ & $\mathrm{Tc}\left({ }^{\circ} \mathrm{C}\right)$ & $\mathrm{K} 1\left(\times 10^{6} \mathrm{erg} / \mathrm{cc}\right)$ & $\mathrm{Br}(\mathrm{kG})$ & $\mathrm{HcJ}(\mathrm{kOe})$ & $\mathrm{Ir} / \mathrm{Is}(\%)$ & $\mathrm{Hk} / \mathrm{HcJ}(\%)$ \\
\hline $\mathrm{Sr}(\mathrm{LiFe}) \mathrm{ZnW}$ & 4.69 & 440 & 2.3 & 4.32 & 0.64 & 92.1 & 57.9 \\
\hline $\mathrm{Ba}(\mathrm{LiFe}) \mathrm{ZnW}$ & 4.78 & 430 & 2.0 & 4.60 & 0.60 & 96.1 & 94.0 \\
\hline
\end{tabular}

\subsection{M-type ferrite}

The practical limit of $\mathrm{Br}$ and (BH)max in M-type ferrite magnets was considered to be around 4.4kG and 4.7MGOe, respectively. Despite of a great number of studies concerning cation substitution in the M-structure, very few attempts to increase magnetization have succeeded. As is well known in spinel ferrites, saturation magnetization increase when nonmagnetic ions such as $\mathrm{Zn}$ occupy tetrahedral $4 \mathrm{fi}$ sites in the $\mathrm{M}$-structure because $\mathrm{Fe}^{3+}$ at $4 \mathrm{fl}$ sites has a down-spin. As shown below, there are three possible ways of compensating for the difference in valency $\left(\mathrm{Zn}^{2+} \rightarrow \mathrm{Fe}^{3+}\right)$ : 
(1) $1 / 2 \mathrm{Zn}^{2+}+1 / 2 \mathrm{M}^{4+} \rightarrow \mathrm{Fe}^{3+}$ (M: Sn, Ti, $\mathrm{Zr}, \mathrm{Mn}$ ) or $2 / 3 \mathrm{Zn}^{2+}+1 / 3 \mathrm{M}^{5+} \rightarrow \mathrm{Fe}^{3+}(\mathrm{M}: \mathrm{V}, \mathrm{Sb}, \mathrm{Nb}, \mathrm{Ta})$ or $3 / 4 \mathrm{Zn}^{2+}+1 / 4 \mathrm{M}^{6+} \rightarrow \mathrm{Fe}^{3+}(\mathrm{M}: \mathrm{W}, \mathrm{Mo})$

(2) $\mathrm{SrFe}^{3+}{ }_{12-x} \mathrm{Zn}^{2+} \mathrm{xO}^{2-19-x \mathrm{~F}^{-} \mathrm{x}}$

(3) $\mathrm{Sr}^{2+{ }_{1-x}} \mathbf{R}^{3+} \mathrm{Fe}^{3++_{12-x} \mathrm{Zn}^{2+}{ }_{x} \mathrm{Oig}}$ (R: Y, La, Nd, Sm, Bi) or $\mathrm{Sr}^{2+}{ }_{1-x} \mathbf{R}^{4+}{ }_{3 \times / 4} \mathrm{Fe}^{3+}{ }_{12-x} \mathrm{Zn}^{2+}{ }_{x} \mathrm{O} 19$ (R: $\mathrm{Ce}, \mathrm{Pr}$ )

Despite of many studies [14], method-(1) dose not obviously improve saturation magnetization because $\mathbf{M}$ ions may also occupy upper-spin sites. The problem with method-(2) is the vaporization of fluorine thus (F-substituted) single $\mathbf{M}$-phase is difficult to obtain.

Research at TDK therefore has recently focused on method(3). Among Lanthanoids, La was the most suitable for substitution for $\mathrm{Sr}$ because it has similar ionic radius [15]; a small amounts of $\mathrm{Na}, \mathrm{K}, \mathrm{Rb}$ and $\mathrm{Bi}$ were also included besides Lanthanoids. The properties of sintered anisotropic samples substituted with $\mathrm{La}$ and $\mathrm{Zn}$ were studied in detail and presented in this conference [16]. Figure 7 shows the $l-H$ hysteresis curve of newly developed material $(x=0.3)$ which indicates the highest (BH)max value obtained.

\section{CONCLUSION}

Processes for preparing submicron-sized particles, for high orientation and for high density are significant for obtaining high performance ferrite magnets. Outstanding high performance $\mathrm{Sr}$ - and $\mathrm{Ba}$-ferrite magnets were obtained, having $\mathrm{Br}=0.44 \mathrm{~T}(4.4 \mathrm{kG}), \mathrm{HcJ}=320 \mathrm{kA} / \mathrm{m} \quad(4.0 \mathrm{kOe})$ and $\mathrm{Br}=0.43 \mathrm{~T}(4.3 \mathrm{kG}), \mathrm{HcJ}=290 \mathrm{kA} / \mathrm{m}(3.6 \mathrm{kOe})$, respectively. Furthermore, by the addition of $\mathrm{SiO}_{2}-\mathrm{SrO}$ or $\mathrm{SiO} 2-\mathrm{BaO}$, we succeeded in making equal the shrinkage ratio in the $a$ and c-axes of anisotropic Ba-ferrite.

By the spin-control approach to increasing magnetization, $\mathrm{La}$ and $\mathrm{Zn}$ substituted Sr-ferrite magnets were developed with extremely high value of $\mathrm{Br}=0.46 \mathrm{~T} \quad(4.6 \mathrm{kG})$ and $(\mathrm{BH}) \mathrm{max}=41 \mathrm{~kJ} / \mathrm{m}^{3}$ (5.2MGOe). These materials are compared with conventional materials (FB-series) in fig. 8 .

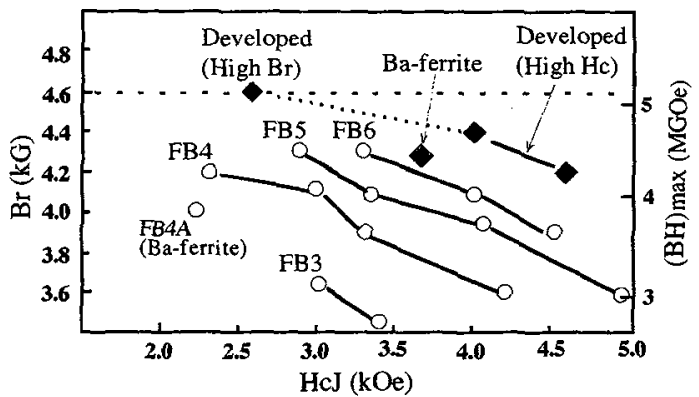

Figure 8: Magnetic properties of developed materials.

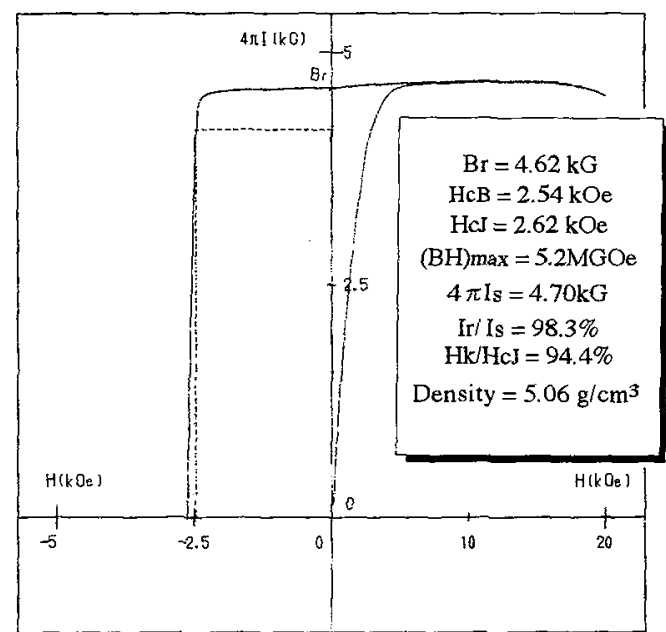

Figure 7: Magnetic properties of developed materials.

\section{References}

[1] J.J.Went, G.W.Rathenau, E.W.Gorter and G.W.van Oosterhout, Philips techn.Rev. 13 (1952) 194-208

[2] H.Kojima, Ferromagnetic Materials 3 (North-Holland Publishing Company, Amsterdam 1982) pp.305-391

[3] H.Taguchi, F.Hirata, T.Takeishi, Y.Tokoyama and T.Mori, J.Japan Soc. Powder and Powder Metallurgy 39(1992)959-963

[4] H.Taguchi, F.Hirata, T.Takeishi and T.Mori, "Dry process for Submicron Sr-ferrite Particles", Japan Soc. Powder and

Powder Metallurgy Spring Meeting, Kyoto (1994) pp.292

[5] H.Taguchi, N.Nishio, F.Hirata, T.Takeishi and T.Mori, J.Mag. Soc. Japan 18 (1994) 197-200

[6] B.E.Warren and B.L.Averbach, J.Appl.Phys. 21 (1950) 595-599

[7] H.Taguchi, F.Hirata, T.Takeishi and T.Mori, "High Performance Ferrite Magnets", ICF6,Tokyo (1992), T.Yamaguchi and M.Abe Eds. pp.1118-1121

[8] H.Taguchi, F.Hirata and T.Takeishi, J.Japan Soc. Powder and Powder Metallurgy 43 (1996) 19-24

[9] F.K.Lotgering, P.H.G.M.Vromans and M.A.H.Huyberts, J.Appl.Phys. 51 (1980) 5913-5918

[10] S.Toyota, "Synthesis and magnetic properties of W-type hexaferrite SrO.2FeO.8Fe2O3", Japan Soc. Powder and Powder Metallurgy Spring Meeting, Tokyo (1996) pp.133

[11] J.P.Mignot, P.Wolfers and J.C.Joubert, J.Magn.Magn.Mater. 51 (1985) 337-341

[12] S.Ram and J.C.Joubert, J.Magn.Magn.Mater. 99 (1991) 133-144

[13] K.Suwa, H.Taguchi and T.Takeishi, "Crystal stability and magnetic properties of Srl-xBax[Zn(LiFe)]W-ferrite", Japan Soc. Powder and Powder Metallurgy Fall Meeting, Sendai (1995) pp.251

[14] K.Haneda and H.Kojima, J.J.Appl.Phys. 12 (1973) 355-360

[15] Andre Deschamps and Felix Bertaut, Academie des Sciences 17 (1957) 3069-3072

[16] H.Taguchi, T.Takeishi, K.Suwa, K.Masuzawa and Y.Minachi, "High Energy Ferrite Magnets", ICF7,Bordeaux (1996) 